\title{
THE OTHER SIDE OF THE COIN: NURSES' VIEWS AND BEHAVIOR ON PHYSICAL RESTRAINT
}

\author{
Cemal Huseyin Guvercin ${ }^{1}$, Menevse Samur², Kubra Pinar Gurkan ${ }^{3}$
}

\begin{abstract}
Aim: To study the views and behaviors of the nurses who apply physical restraint. Research Design: The study was designed as a descriptive study. The data were collected using a questionnaire form and analyzed by chi-square tests. The study was conducted at a university hospital. The convenience sample consisted of 93 voluntary nurses. Findings: The decision to initiate/terminate the physical restraint is mostly (63.4\%) made by the physician and the nurse together, and frequently (96.8\%) wrist belts are used. While one-third of the nurses (33.4\%) apply the restraint for more than 7 days, $21.4 \%$ never loosen the physical restraint. $28 \%$ of the nurses face resistance due to the restraint. $78.5 \%$ of the nurses obtain informed consent for the restraint whereas $51.6 \%$ believe that the consent is not necessary. Only $9.7 \%$ of the nurses record the practice to the patient observation chart. Additionally, there is a relationship between the unit, patients they cared for daily, years in the profession and the nurses' views on restraint $(p \leq 0.05)$. Conclusion: It is necessary to improve the nurses' awareness and ethical sensitivity about physical restraint. Professional development of the nurses regarding physical restraint should be maintained continuously from the beginning of their undergraduate education. An institutional committee should be established to support decision-making and monitor the restraint processes.
\end{abstract}

Key words: behavior, informed consent, nurse, nursing practice, physical restraint, professional ethics

\section{El otro lado de la moneda: puntos de vista y comportamiento de las enfermeras en relación a la restricción médica}

Resumen: Objetivo: Estudiar los puntos de vista y comportamientos de las enfermeras que aplican restricción física. Diseño de investigación: Estudio descriptivo realizado en un Hospital Universitario. Los datos se recolectaron usando un cuestionario y analizando los textos mediante chi-square. La muestra de conveniencia consistió en 93 enfermeras voluntarias. Resultados: La decisión de iniciar/terminar la restricción física corresponde mayoritariamente al médico y la enfermera en conjunto $(63,4 \%)$, y frecuentemente se usa atadura de muñecas $(96,8 \%)$. Mientras que un tercio de las enfermeras $(33,4 \%)$ aplica la restricción por más de 7 días, 21,4\% nunca afloja la restricción física. 28\% de las enfermeras muestran resistencia a aplicar restricción. 78,5\% obtienen consentimiento informado para restringir, mientras que $51,6 \%$ cree que no es necesario el consentimiento. Solamente $9,7 \%$ de las enfermeras registra la práctica en la hoja de observación del paciente. Además, existe relación entre la unidad, pacientes que cuidan diariamente, años en la profesión y puntos de vista de las enfermeras sobre la restricción ( $\mathrm{p} \leq 0.05)$. Conclusión: Es necesario mejorar la conciencia y sensibilidad ética sobre la restricción física. Debiera mantenerse continuamente el desarrollo profesional de las enfermeras sobre la restricción física desde el comienzo de la educación de pregrado y establecer un comité institucional para asistir la decisión de monitorear los procesos de restricción.

Palabras clave: comportamiento, consentimiento informado, enfermera, práctica de enfermería, restricción física, ética profesional

O outro lado da moeda: A visão e o comportamento dos enfermeiros na contençáo física

Resumo: Fundo: A contenção física é uma prática amplamente utilizada que inclui problemas éticos. A análise dos pontos de vista e comportamentos de enfermeiros que aplicam a contenção física são importantes para determinar os problemas na prática e para encontrar soluçóes. Objetivo: Estudar as visóes e comportamentos de enfermeiro que fazem uso da contençáo física. Projeto de pesquisa: $\mathrm{O}$ estudo foi concebido como um estudo descritivo. Os dados foram coletados utilizando um formulário de questionário e analisados pelos testes do qui-quadrado. $\mathrm{O}$ estudo foi realizado em um hospital universitário. A amostra de conveniência consistiu de 93 enfermeiros voluntários. Conclusōes: A decisão de iniciar/encerrar a contenção física é principalmente $(63,4 \%)$ feita pelo médico e enfermeiro juntos, e frequência de uso dos cintos de pulso (96,8\%). Enquanto um terço dos enfermeiros $(33,4 \%)$ aplicam a retenção por mais de 7 dias, $21,4 \%$ nunca soltam a contenção física. $28 \%$ dos enfermeiros encaram resistência devido a retenção. $78,5 \%$ dos enfermeiros obtém consentimento prévio para retenção, enquanto $51,6 \%$ acreditam que o consentimento não é necessário. Apenas $9,7 \%$ dos enfermeiros registram a prática na ficha de observação do paciente. Além disso, existe uma relação entre a unidade, os pacientes que eles cuidam diariamente, anos na profissão e visão dos enfermeiros a cerca da contenção $(\mathrm{p} \leq 0,05)$. Conclusão: É necessário melhorar a consciência e sensibilidade ética dos enfermeiros sobre contençáo física. O desenvolvimento profissional do enfermeiro considerando a contenção física deve ser mantido continuamente a partir do início de sua graduação. Uma Comissão institucional deve ser estabelecida para apoiar a tomada de decisão e acompanhar os processos de retenção.

Palavras-chave: comportamento, consentimento informado, enfermeiro, enfermagem, contençáo física, ética profissional

${ }^{1}$ Dokuz Eylul University, Faculty of Medicine, Department of History of Medicine and Ethics, Izmir, Turkey. Division of Developmental Medicine, Boston Children's Hospital, Harvard Medical School, Boston, Massachusetts, USA

Correspondence: cemalcin@yahoo.com

${ }^{2}$ Department of Nursing Management, Nursing Faculty, Dokuz Eylul University, Balcova, Izmir, Turkey

${ }^{3}$ Department of Public Health Nursing, Faculty of Nursing, Dokuz Eylul University Balcova, Izmir, Turkey 


\section{Introduction}

Physical restraint (PR) is to restrict a person's freedom of movement by using devices such as belts (wrist, ankle), bilateral bedrails, limb, trunk, chairs(1). PR is applied to prevent the patients from damaging themselves and their environment, keep the patients under control and prevent the removal of their connections(2,3). Despite its benefit to the patient, it is an act, which limits the autonomy of the patient, that can be harmful and abusive. The use of improper PR may lead to physical, functional, and psychological damage in the patient(4). Although it is a controversial issue in terms of ethical principles such as respect for the individual/autonomy, maleficence/beneficence, and it is recommended as a last resort in practice, PR is widely used(5-8). While worldwide prevalence of PR varies between $7-75 \%$, in Turkey, particularly in intensive care services, this percentage increases upto $90 \%(9-12,6)$. Despite the standards of PR determined by the guidelines $(4,5)$ studies show that health professionals have insufficient knowledge and practice about many subjects such as the adverse effects, risk factors, and alternative methods of $\mathrm{PR}(2,6,12-14)$.

Patient well-being is greatly influenced by ethical decisions made by well-trained health personnel with ethical sensitivity(15). In particular, the nurses have key roles in the healthcare team as the decision-making process of PR implementation, follow-up, and informing the physician about termination(16).

urses usuallay find PR an easy option especially when human resources are inadequate. It was determined that nurses use PR to encusre patient treatment compliance, or/and a method of discipline and even punishment. It is a remarkable emphasis that PR is often seen as the easiest option but rarely applied in ethical standards(17).

The decision of using PR is difficult and stressful for the nurses since this require an evaluation of complex components such as patient preferences, medical indications, quality of life, and other factors (religion, culture, law, etc.). An error or incorrect assessment of the decision-making process leads to inappropriate use of PR and ends up with adverse events. Improper PR practice poses a sig- nificant threat to human rights, patient honor, patient autonomy and patient well-being. For this reason, it is an important ethical issue that can lead to legal sanctions(18). The understanding of how PR practices are done clinically, and how evidence and skills are reflected in the clinic is vital for preventing inappropriate PR practices, ensuring patient benefits, cooperating with patients and his/her relatives, protecting patient rights and prevent from abusing patient autonomy on the side adverse reactions. The correct understanding of the nurses' practice, attitude, knowledge and skills will allow propoer improvement activities plan and the creation of effective strategies. PR practice should be more thoroughly studied since it is commonly used in our country despite the fact that it carries the risk of harming the patient and should be applied with great care, and despite the insufficient legal regulations, lack of supervision regarding its use, its exclusion from the undergraduate curriculum and ignored ethical problems related with the practice.

\section{Aims and objectives}

The aim of this study is to analyze the views and behaviors of the nurses who work in a university hospital and apply PR. Secondary aim of the study is to investigate the relationship between the sociodemographic traits (age, marital status, education, working unit, years in the profession, patients they cared for daily) of the nurses and their views on PR.

\section{Research Design}

\section{Sample and data collection}

The study, which was planned as a descriptive study, was conducted in the internal medicine, surgery, and intensive care units of a university hospital (Izmir, Turkey). Of non-probability sampling methods, convenience sampling was used; of the nurses who worked in the relevant units and applied PR before, 93 volunteer nurses constituted the study group.

\section{Instruments}

Sociodemografic Traits Form: Includes nurses' sex, age, marital status, education, working unit, years 
in the profession, patients they cared for daily.

Questinnaire Form: It consists of a total of 26 questions to evaluate the views (12 questions) and behaviors (14 questions) of the nurses toward PR.

\section{Ethical Considerations}

Written permissions were obtained from the Non-Invasive Research Ethics Board (Decision date: 18.09.2015, Protocol code: 2293-GOA, no. 2015122-06), and the hospital. In addition, verbal consent of the participants was obtained.

\section{Data Analyses}

Using the descriptive statistics, a preliminary analysis was performed on the data provided. The results were expressed as number of observations $(\mathrm{n})$, mean \pm standard deviation $(\mathrm{X} \pm \mathrm{SD})$ percentages (\%). In order to determine the relationships between categorical variables, Chi-square tests were performed. Categorical variables were statistically evaluated by Pearson $X^{2}$ test for one way and two way tables. In some cells of the contingency tables, the frequency was small and the expected frequency was less than 5. Thus, Chi square test with Monte Carlo Simulation method and Fisher's Exact test were used for these tables. These methods provide a means to obtain accurate results when the data fail to meet any of the underlying assumptions necessary for reliable results using the standard asymptotic method.

Data analyses were performed using the Statistical Package for the Social Sciences, version 19.0 (IBM Corp, 2010). A $p$ value of $\leq 0.05$ was considered statistically significant, and a $p$ value of $\leq 0.01$ was considered highly statistically significant.

In sociodemographic terms, $96.0 \%$ of the nurses were female, and the mean age was $34.08 \pm 6.67$. $55.9 \%$ of the nurses were married, $77.4 \%$ had undergraduate degrees, $39.8 \%$ were working in surgery, $29 \%$ in internal medicine, and $31.2 \%$ in the intensive care unit. While $53.8 \%$ of nurses have more than 10 years of professional experience, $30.1 \%$ they cared for $1-5$ patients daily (Table 1 ).

Table 1: Sociodemografic Traits of Nurses

\begin{tabular}{|c|c|c|}
\hline Characteristics & $\mathrm{n}$ & $\%$ \\
\hline \multicolumn{3}{|l|}{ Marital status } \\
\hline Married & 52 & 55.9 \\
\hline Single & 41 & 44.1 \\
\hline \multicolumn{3}{|l|}{ Education } \\
\hline Associate degree or lesser than associate degree & 3 & 3.2 \\
\hline Undergraduate & 72 & 77.4 \\
\hline $\mathrm{PhD}$ & 18 & 19.4 \\
\hline \multicolumn{3}{|l|}{ Working unit } \\
\hline Internal medicine & 27 & 29.0 \\
\hline Surgery & 37 & 39.8 \\
\hline Intensive care & 29 & 31.2 \\
\hline \multicolumn{3}{|l|}{ Years in the profession } \\
\hline$<=10$ years & 43 & 46.2 \\
\hline$>10$ years & 50 & 53.8 \\
\hline \multicolumn{3}{|l|}{ Patients they took care of Daily } \\
\hline 1-5 patient(s) & 28 & 30.1 \\
\hline 6-10 patients & 22 & 23.7 \\
\hline $11-15$ patients & 23 & 24.7 \\
\hline$>=16$ patients & 20 & 21.5 \\
\hline
\end{tabular}


The Other Side of the Coin: Nurses' Views and Behavior on Physical Restraint - Cemal Huseyin Guvercin et al.

Table 2: Nurses' Behavior Toward Pysical Restraint

\begin{tabular}{|c|c|c|c|}
\hline Factors & $\mathrm{n}(\%)$ & $\begin{array}{l}\text { Test statistics } \\
\text { Pearson's X }\end{array}$ & $\mathrm{p}$ \\
\hline \multicolumn{4}{|l|}{ Decision maker } \\
\hline Physician & \multirow{3}{*}{$\begin{array}{l}25(26.9) \\
9(9.7) \\
59(63.4)\end{array}$} & \multirow{3}{*}{42.07} & \multirow[t]{3}{*}{$<0.001$} \\
\hline Nurse & & & \\
\hline Physician and Nurse & & & \\
\hline \multicolumn{4}{|l|}{ Duration of PR } \\
\hline Less than 24 hours & $28(30.0)$ & \multirow[t]{3}{*}{30.07} & \multirow[t]{3}{*}{$<0.001$} \\
\hline 1-7 days & $34(36.6)$ & & \\
\hline Up to 7 days & $31(33.4)$ & & \\
\hline \multicolumn{4}{|l|}{ The loosen of PR } \\
\hline Never & $20(21.4)$ & \multirow[t]{4}{*}{12.86} & \multirow[t]{4}{*}{$<0.05$} \\
\hline Once every $12-24$ hours & $22(23.7)$ & & \\
\hline Once every 4-12 hours & $22(23.7)$ & & \\
\hline Once every $0-4$ hours & $29(31.2)$ & & \\
\hline \multicolumn{4}{|l|}{ The most frequently used type of $\mathrm{PR}^{*}$} \\
\hline Wrist belts & $90(96.8)$ & 81.39 & $<0.001$ \\
\hline Bilateral bedrails & $81(87.1)$ & 51.19 & $<0.001$ \\
\hline Ankle belts & $66(71.0)$ & 16.36 & $<0.001$ \\
\hline Whole body restraints & $22(23.7)$ & 25.82 & $<0.001$ \\
\hline \multicolumn{4}{|l|}{ Reason to use* } \\
\hline To prevent the removal of connections (tubing, etc.) & $87(93.5)$ & 70.55 & $<0.001$ \\
\hline Prevent to fall & $66(71.0)$ & 16.36 & $<0.001$ \\
\hline To keep the patient's behaviors under control & $40(43.0)$ & 1.82 & 0.178 \\
\hline To facilitate care and treatment & $22(23.7)$ & 25.82 & $<0.001$ \\
\hline \multicolumn{4}{|l|}{ The most observed complications* } \\
\hline Increased agitation & $67(72.0)$ & 18.08 & $<0.001$ \\
\hline Altered skin integrity (abrasion, edema etc.) & $52(55.9)$ & 1.30 & 0.254 \\
\hline Delirium & $10(10.8)$ & 57.30 & $<0.001$ \\
\hline Decubitus ulcer & $8(8.6)$ & 63.75 & $<0.001$ \\
\hline Decreased self-confidence and self-esteem & $8(8.6)$ & 63.75 & $<0.001$ \\
\hline To fall out of bed & $1(1.1)$ & 89.04 & $<0.001$ \\
\hline \multicolumn{4}{|c|}{ Have you experienced a situation where the patient is harmed due to a PR-related issue? } \\
\hline Yes & $66(71.0)$ & \multirow[t]{2}{*}{16.36} & \multirow[t]{2}{*}{$<0.001$} \\
\hline No & $27(29.0)$ & & \\
\hline \multicolumn{4}{|c|}{ Would you continue applying PR even after the risk of self-injury is eliminated? } \\
\hline Yes & $14(15.1)$ & \multirow[t]{2}{*}{45.43} & \multirow[t]{2}{*}{$<0.001$} \\
\hline No & $79(84.9)$ & & \\
\hline
\end{tabular}




\begin{tabular}{|c|c|c|c|}
\hline \multicolumn{4}{|l|}{ Have you ever experienced resistance to PR from the patients/relatives? } \\
\hline Yes & \multirow{2}{*}{$\begin{array}{l}26(28.0) \\
67(72.0)\end{array}$} & \multirow{2}{*}{18.08} & \multirow{2}{*}{$<0.001$} \\
\hline No & & & \\
\hline \multicolumn{4}{|l|}{ Reasons for facing resistance from patient/relatives* } \\
\hline Believing that the patient is suffering & $55(59.1)$ & 3.11 & 0.078 \\
\hline Not believing in the necessity of the practice & $41(44.1)$ & 1.30 & 0.254 \\
\hline Perception of the PR as an inhuman-degrading practice & $32(34.4)$ & 9.04 & $<0.01$ \\
\hline Being uninformed about the practice (including the consent) & $19(20.4)$ & 32.53 & $<0.001$ \\
\hline Complications & $18(19.4)$ & 34.94 & $<0.001$ \\
\hline Previous negative experiences of patients/relatives & $17(18.3)$ & 37.43 & $<0.001$ \\
\hline Prolonged application of PR & $17(18.3)$ & 37.43 & $<0.001$ \\
\hline Believing that the health professionals apply the PR for their own comfort & $17(18.3)$ & 37.43 & $<0.001$ \\
\hline Thinking that PR is against patient autonomy & $11(11.8)$ & 54.20 & $<0.001$ \\
\hline \multicolumn{4}{|l|}{ Do you obtain informed consent for PR? } \\
\hline Yes & $73(78.5)$ & 30.20 & $<0.001$ \\
\hline No & $20(21.5)$ & & \\
\hline \multicolumn{4}{|l|}{ Do you think informed consent is necessary for PR? } \\
\hline $\mathrm{e}$ & $45(48.4)$ & 0.10 & 0.756 \\
\hline No & $48(51.6)$ & & \\
\hline \multicolumn{4}{|l|}{ Do you record PR to the nurse's patient observation chart? } \\
\hline Yes & $9(9.7)$ & 60.48 & $<0.001$ \\
\hline No & $84(90.3)$ & & \\
\hline \multicolumn{4}{|l|}{ Should PR be recorded to the nurse's patient observation chart? } \\
\hline Yes & $85(91.4)$ & 63.75 & $<0.001$ \\
\hline No & $8(8.6)$ & & \\
\hline
\end{tabular}

* More than one choice is marked.

\section{Findings}

Physicians and nurses (63.4\%) mostly made the decision to initiate/terminate PR together.. Nurses generally participate in 3 out of every $4 \mathrm{PR}$ decisions $(74.1 \%)$. While one-third of the nurses (33.4\%) applied the PR for more than 7 days, $21.4 \%$ never loosen the PR. While the most commonly used type of PR was wrist belt (96.8\%), the most common cause of applying PR was to prevent the patient from removing the connec- tions (93.5\%). The most frequently observed complications were increased agitation $(72 \%)$ and alteration of skin integrity (55.9\%). The rate of nurses who experienced a situation in which the patient was harmed due to not using PR was $71 \%$. $15.1 \%$ of the nurses stated that they would continue to apply PR even after the risk is eliminated. $28 \%$ of the nurses faced resistance from patients/ relatives due to PR. The most important causes of the resistance were believing that the patient is in pain $(59.1 \%)$, not believing in the necessity of 
Table 3: Nurses' Views on Physical Restraint

\begin{tabular}{|l|l|l|l|l|}
\hline Items & Agree (\%) & Disagree (\%) & $\mathrm{X}^{2}$ & $\mathrm{p}$ \\
\hline PR is always applied for the benefit of the patient. & $86(92.5)$ & $7(7.5)$ & 67.11 & $<0.001$ \\
\hline PR is a practice that should be removed as soon as possible. & $65(69.9)$ & $28(30.1)$ & 14.72 & $<0.001$ \\
\hline PR facilitates the care and treatment of the patient. & $60(64.5)$ & $33(33.5)$ & 7.84 & $<0.001$ \\
\hline PR is a routine medical practice. & $22(23.7)$ & $71(76.3)$ & 25.82 & $<0.001$ \\
\hline PR can be applied even in the lack of informed consent. & $48(51.6)$ & $45(48.4)$ & 0.097 & 0.756 \\
\hline $\begin{array}{l}\text { In terms of the way it restricts freedom, PR can be compared to } \\
\text { handcuffing a convict. }\end{array}$ & $48(51.6)$ & $45(48.4)$ & 0.10 & 0.76 \\
\hline PR is a difficult and painful application to bear. & & & & \\
\hline PR facilitates is a degrading practice. & $45(48.4)$ & $48(51.6)$ & 0.10 & 0.76 \\
\hline I have difficulty in applying PR to child patients. & $25(26.9)$ & $68(73.1)$ & 19.88 & $<0.001$ \\
\hline I have difficulty in applying PR to terminal patients. & $63(67.7)$ & $30(32.3)$ & 11.71 & $<0.001$ \\
\hline I have difficulty in applying PR to elderly patients. & $47(50.5)$ & $46(49.5)$ & 0.01 & 0.92 \\
\hline $\begin{array}{l}\text { Establishment of a PR monitoring and evaluation committee } \\
\text { would be useful to prevent ethical problems. }\end{array}$ & $66(71.0)$ & $27(29.0)$ & 16.36 & 0.60 \\
\hline
\end{tabular}

the practice (44.1\%), perceiving PR as an inhumane-degrading practice $(34.4 \%)$ and being uninformed about the practice $(20.4 \%)$. Although $78.5 \%$ of the nurses obtained informed consent for PR, 51.6\% did not believe that informed consent is necessary. Only $9.7 \%$ of the nurses stated that it is necessary to record the practice to the patient observation chart whereas $91.4 \%$ state that it is necessary to record the practice to the patient observation chart (Table 2).

$92.5 \%$ of the nurses think that PR is applied for the benefit of the patient, $69.9 \%$ think that it should be removed as soon as possible, and $64.5 \%$ think that it facilitates care and treatment. $23.7 \%$ of the nurses think that $\mathrm{PR}$ is a routine practice, 51.6\% think that PR can be performed even in the lack of informed consent. In addition, 51.6\% of the nurses think that it can be compared to handcuffing of a convict, $48.5 \%$ think that PR is hard and painful, and $26.9 \%$ think that $\mathrm{PR}$ is degrading.

While almost half of the nurses state that they have difficulty in applying PR, more nurses have difficulty in applying PR to the child patients. $71 \%$ of the nurses believe that "Physical Restraint Monitoring and Evaluation Committee" would be helpful in preventing ethical problems (Table 3).

When the relationship between the sociodemographic traits of the nurses and their views on PR is analyzed, it is seen that nurses in the intensive care unit $(72.5 \%)$ agree more with the statement that PR can be applied even in the lack of informed consent $(p<0.05)$. Nurses with more than 10 years of professional experience $(80 \%)$ agree more with the statement that "restraint should be removed as soon as possible" more than those with less experience $(58.1 \%)(p<0.05)$. While $45 \%$ of the nurses who cared for more than 15 patients daily accept PR as "a routine practice" $(\mathrm{p}<0.05)$, nurses who cared for less patients daily were less likely to participate (17.8\%).

No significant relationship was found between other sociodemographic traits of nurses than working unit, years in profession, and the number of patients the they take care for daily and their views on PR (Table 4).

\section{Discussion}

\section{Nurses' Behavior Toward Physical Restraint}

Decision maker: In our study, it was found that 
Table 4: The Relationship Between Sociodemographic Traits of the Nurses and Their Views on Physical Restraint

\begin{tabular}{|c|c|c|c|c|c|c|}
\hline \multirow[t]{3}{*}{ Working unit } & \multicolumn{4}{|c|}{ PR can be applied even in the lack of consent. } & \multirow{2}{*}{\multicolumn{2}{|c|}{\begin{tabular}{|l} 
Total \\
$\mathrm{X}^{2}=9.05$ \\
$\mathrm{p}=0.011$
\end{tabular}}} \\
\hline & \multicolumn{2}{|l|}{ Agree } & \multicolumn{2}{|c|}{ Disagree } & & \\
\hline & $\mathrm{n}$ & $\%$ & $\mathrm{n}$ & $\%$ & $\mathrm{n}$ & $\%$ \\
\hline Internal medicine & 14 & 51.9 & 13 & 48.1 & 27 & 100 \\
\hline Surgery & 13 & 35.1 & 24 & 64.9 & 37 & 100 \\
\hline Intensive care & 21 & 72.4 & 8 & 27.6 & 29 & 100 \\
\hline Total & 48 & 51.6 & 45 & 48.4 & 93 & 100 \\
\hline \multirow{3}{*}{$\begin{array}{l}\text { Years in the } \\
\text { profession }\end{array}$} & \multicolumn{4}{|c|}{$\mathrm{PR}$ is a practice that should be removed as soon as possible. } & \multirow{2}{*}{\multicolumn{2}{|c|}{$\begin{array}{l}\text { Total } \\
\text { Fisher's Exact test } \\
p=0.025\end{array}$}} \\
\hline & \multicolumn{2}{|c|}{ Agree } & \multicolumn{2}{|c|}{ Disagree } & & \\
\hline & $\mathrm{n}$ & $\%$ & n & $\%$ & n & $\%$ \\
\hline$<=10$ years & 25 & 58.1 & 18 & 41.9 & 43 & 100 \\
\hline$>10$ years & 40 & 80.0 & 10 & 20.0 & 50 & 100 \\
\hline Total & 65 & 69.9 & 28 & 30.1 & 93 & 100 \\
\hline \multirow{3}{*}{$\begin{array}{l}\text { Patients they } \\
\text { cared for daily }\end{array}$} & \multicolumn{4}{|c|}{ PR is a routine medical practice. } & \multirow{2}{*}{\multicolumn{2}{|c|}{$\begin{array}{l}\text { Total } \\
\text { Fisher's Exact test } \\
\mathrm{p}=0.017\end{array}$}} \\
\hline & \multicolumn{2}{|c|}{ Agree } & \multicolumn{2}{|c|}{ Disagree } & & \\
\hline & $\mathrm{n}$ & $\%$ & n & $\%$ & $\mathrm{n}$ & $\%$ \\
\hline$<=15$ patients & 13 & 17.8 & 60 & 82.2 & 73 & 100 \\
\hline$>15$ patients & 9 & 45.0 & 11 & 55.0 & 20 & 100 \\
\hline Total & 22 & 23.7 & 71 & 76.3 & 93 & 100 \\
\hline
\end{tabular}

PR is often applied upon the joint decision of the physician and nurse and this is in agreement with the legal regulations in Turkey $(20,21)$. There are different practices around the world regarding who makes the decision to use restraint. Evidencebased applications show that the decision maker is the physician (22), whereas The Joint Commission claim that the decision should be made by the physician or licensed independent practitioner(23).

In Taiwan, in addition to the physician, one of the family members or a legal guardian also has to approve of the application of $\mathrm{PR}(6)$. In the study by Jiang(24), it was found that the decision to apply PR was made by the nurses. Instead of leaving the decision of using PR on the patient to the individual responsibility of the physician or nurse alone, it can be said that making the decision via an "extended partnership and consensus" that includes the health professionals and the patient/ relatives would increase the patient's compliance and expected benefit, and reduce complications and non-standard practices. The involvement of the patient or his/her legal representative in decision-making processes will support the protection of the patient's autonomy, by limiting the possible paternalistic attitudes of the healthcare professionals. Decision makers must consider PR as the last resort after trying other alternatives that were ineffective.

Duration of application and loosen: Although $\mathrm{PR}$ is a practice which should be performed as a last resort and removed as soon as possible, it is a striking finding that the considerably $(33.4 \%)$ 
nurses in our study applied PR for more than 7 days and did not regularly loosen or never loosen the application. Long-term implementation of PR or irregular intervals indicate that it is not applied attentively and in accordance with the ethical standards. The long term implementation of PR decision can be abusive altough it could be right at the beginning. In the study by Evans(25), mean PR duration varied between 2.7-4.5 days whereas in the study by Fugger(26) this duration extended upto 50 days. In our study, while the professional experience of the nurses affects the view on PR positively, the number of patients cared daily affects nurses practises and views negatively. The tendency to terminate PR as early as possible is high among the experienced nurses. This suggests that the experienced nurses witnessed more of the PR damage and considered the practice as risky. The rate of regarding PR as a routine practice is high among the nurses with excessive workload. Increased workload can be a significant risk in terms of reducing ethical sensitivity among nurses, extending PR application period, and long term intervals.

In general, duration of the PR should be kept to a minimum and the decision of PR should be reviewed in every 24 hours at the latest $(21-23,27,28)$. Regarding the duration of application " 2 hours PR, 15 minutes loosen" is recommended for the residents of the nursing home(6). However, despite the recommendations, there are still uncertainties associated especially with the maximum duration of PR and loosen period. In this respect, taking into account the characteristics of patient, disease and treatment, it is necessary to determine the average duration of PR and loosen.

Type of PR: In this study, in paralel with the literature, the most commonly used types of PR were wrist/ankle restraint and raise the bed rails $(24,29)$. The choice of PR should meet the patient's requirements(30). Choice of PR is affected by the personal traits of the patient (agitation, aggressiveness, etc.) in addition to the organizational factors such as the patient profile in the outpatient clinic, staff culture, and available human resources $(31,32)$. The fact that most of the nurses in our study compared PR to the handcuffing of a prisoner and evaluate it as difficult and painful, but they still have to implement it reveals the dilemma they experience. While the patients state that all types of PR have a negative impact on them(33), it was found that the patients whose bed rails were raised tried to climb over the bed rails and had the risk of suffocation(31). Although the conditions make PR obligatory, use of all types of PR should be reduced(34). Distraction techniques "music, television, taking the patient for a walk, coloring, writing, having a family member read to or talk with the patient" can be used to reduce the need for PR(35).

Causes of applying PR: PR is frequently used to prevent the removal of the connections (tubes, nasogastric catheter, etc.), to prevent the patient from falling, and to have control over the patient $(24,25,36,37)$. If the nurses experience a situation in which the patient is harmed due to the lack of PR, this can be a factor which would increase the use of PR in the future. In fact, some of the nurses state that they would continue applying the PR even after the risk of harm is eliminated. However, even if PR is applied, patients can remove their connections and fall (24,36-38). Work overload and understaffing cause the nurses to be unable to determine the appropriate indication and act without ethical sensitivity, and apply PR to maintain the patient's safety and easily perform their duties(24). PR can turn into a "guarantee behavior" in which the patient is inactivated/pacified and his/her participation is ignored. The restraint is implemented with the thought of "ensuring absolute benefit to the patient and preventing him/ her from being harmed. "This is a very solid reason and gives the healthcare professionals a paternalistic advantage. This paternalistic attitude also sets the ground for PR to be questioned less and used more commonly.

Complications: It has been shown that atony, muscle weakness, urinary/fecal incontinence, decubitus ulcers and related infections, insomnia, agitation, confusion, fear, depression, decreased self-confidence and self-respect, body image deterioration, sensory deprivation, asphyxia and asphyxia-related death can occur due to prolonged PR(39-41). Majority of the nurses in this study observed PR-related complications. When applying PR, the expected benefit should be worth taking the risk of complication. In addition, practices to prevent any complications (loosen, continuous 
and regular observation, communication with patient etc.) should be performed.

The medical problems associated with PR may be due to the non-standard practices of healthcare professionals as well as the nature of the practice. Therefore, minimizing the implementation of PR as much as possible and improving healthcare professionals through training and follow-up will play an active role in reducing these problems.

Informed consent and resistance: Informed consent is a process that protects the autonomy of the individual in medical practices(42). Today, obtaining informed consent is not only an ethical obligation, but also a legal compulsion(43). Consent should also be obtained from the patients to be applied PR or their legal representative. In case the patient is likely to lose his/her consciousness, the advance directive, which is taken when he/she is conscious, is also valid. However, it is striking that there are nurses, as also in our study, who regard PR consent unnecessary or they perform the practice without consent (without a justification like an emergency). This tendency has been found more among the intensive care nurses, similar to Jiang's study(24). In this study, it is significant to see that there are still nurses who apply PR without the informed consent and more than half of the nurses do not believe in the necessity of informed consent. Similar to the study by Jiang, in our study, this tendency was found to be higher in the nurses working in the intensive care unit(24). Complex, unconscious patients in the intensive care unit and common use of PR can cause the nurses to regard the PR as a routine procedure and have reduced ethical sensitivity toward using PR. Belief and attitude of the nurses toward informed consent are affected by factors such as training, years in profession, work environment, unit culture $(33,44)$. In our study, although statistically insignificant, the similarity between the rates of not obtaining informed consent and facing resistance with patients or relatives is striking. The decision of the patient/relatives regarding PR is affected by the information provided to the patient(45). Therefore; most of the factors behind the resistance (being uninformed about the practice, not believing in its necessity) can be eliminated by obtaining an informed consent.
Recording to patient observation chart: It was found that even though necessary follow-ups are performed for patients who were restrained, they were not included in the records and medical documents have missing information regarding PR use(46). While almost all of the nurses believed in the necessity to record the PR, not recording the PR can be related to the format of the patient observation charts which does not accommodate $\mathrm{PR}$, and workload. Not recording the PR can also exacerbate the negative behavior of the personnel. However, guidelines recommend that the patient's treatment plan should include initiation/termination date/hour of the restraint, complications, physician's views, observation notes, etc. $(21,30)$. Observed behavior is influenced by organizational factors such as service culture, workload and control. The fact that PR, which is an invasive application, is not usually recorded to the patient observation chart which indicates not only the inadequacy of knowledge and ethical sensitivity of the nurses but also a structural problem in the institution. Failure in recording PR may negatively affect the regular follow-up of the practice as well as consolidate the false steps of healthcare professionals.

\section{Nurses' Views Toward Pysical Restraint}

Nurses think that restraint is applied for the patient's benefit(24) and it can be performed even if informed consent is not obtained. This represents a paternalistic attitude and results in disregarding the patient autonomy. Even if it is for the benefit of the patient (except urgency), none of the interventions without informed consent can be ethically justified. Similar to the study by Jiang(24), in this study, it was found that nurses see the PR as a routine practice. In our study, it was concluded that with increased number of patients taken care of daily, the tendency to regard PR as a routine practice increases. This result is extremely important as it shows the negative effects of excessive workload on ethical sensitivity. Excessive workload poses a serious risk for proper implementation and follow-up of PR, leading to the extension of PR duration and neglecting regular intervals.

PR is an exceptional method which should be excluded from the routine protocol(17). The nurses should regard $\mathrm{PR}$ as a practice to pay attention to 
rather than a routine practice and as it includes a kind of violence, it should be applied minimally and as a last resort $(3,47)$.

Health professionals accept that PR is very hard for the patients and worry about handling the reactions of the patient, applying the procedure correctly and dealing with physical fatigue, and carry many negative emotions such as fealing guilty(33). In our study, nurses accepted that PR is a difficult practice both for them and the patients and should be removed as soon as possible. Particularly in nurses with more professional experience, the tendency to remove the PR as soon as possible is higher. The fact that the nurses think a committee would be useful shows that they are looking for a solution to overcome the problems they are experiencing, they want to share the risk and they think that a committee to make decisions would be nice.

\section{Conclusion and relevance to clinical practice}

In conclusion, it is important to increase the knowledge, awareness and ethical sensitivity of the nurses about PR. This study can guide the educators to make a call on the sensitivity of the application starting from their undergraduate education, professional development of the nurses regarding PR should be maintained continuously. And also, organizational arrangements should be carried out to regulate negative working conditions of the nurses and protect them from the excessive workload. In addition, establishment of a "Physical Restraint Monitoring and Evaluation Committee" would be useful to support the nurses, manage difficult cases and prevent the violation of patient rights. This committe to be composed of the health professionals other than the team providing care for the patient can monitor the FT implementation as "the third eye" and provide an additional institutional protection for the patient.

In the committee, presence of a clinician, critical care physician, nurse, medical ethicist and if required, pediatrist, psychologist, or psychiatrist can be recommended to evaluate the indications, daily follow-ups and complications of the patients under restraint. As a principle, use of alternative methods and establishment of restraint-free environments should be the main strategy. This study might therefore contribute to attracting attention to the problem of restraint especially in the developing countries and reducing the use of restraint. PR should be applied after the informed consent of the patient or his/her legal representative in accordance with the principles of being the last resort, using the most appropriate method, giving intervals regularly, assessing frequently in terms of complications, and terminating as soon as possible. However, using alternative methods and arranging restraint-free environments at first should be the basic strategy. It is thought that this study will contribute to drawing attention to $\mathrm{PR}$, an important ethics issue particularly in developing countries, emphasizing the importance of professional and ethical competence of the nurses in this regard and reducing the restraint as much as possible.

\section{Limitations}

The study was conducted in only on university hosptial with a relatively small sample size and hince this affects its generalisability. Approximately half of the nurses who had previously applied the restriction were refused to participate in the study. It should be considering that the study was taken on a voluntary basis. 


\section{References}

1. Hamers JP., Meyer G., Köpke S., Lindenmann R., Groven R. \& Huizing AR. Attitudes of Dutch, German and Swiss nursing staff towards physical restraint use in nursing home residents, a cross-sectional study. Int J Nurs Stud. 2009; 46(2): 248-255.

2. Heinze C, Dassen T, Grittner U. Use of physical restraints in nursing homes and hospitals and related factors: a crosssectional study. Journal of Clinical Nursing. 2012; 21(7-8): 1033-1040.

3. Berzlanovich AM, Schöpfer J, Keil W. Deaths due to physical restraint. Deutsches Ärzteblatt International 2012; 109(3), 27

4. Shum CH, Ip MW, Chan YW, Yiu D, Pang WS, Kwok WY, et al. A Quality Improvement Project to Improve and Reduce the Use of Hand Mitt Restraints in Nursing Home Residents. JAMDA 2016; 17: 272-274.

5. Gastmans C. Clinical-ethical considerations on the use of physical restraint. In Hughes R. (Ed.) Rights, risks and restraint-free care of older people. London: Jessica Kingsley Publishers; 2010: 106-119.

6. Huang HC, Huang YT, Lin KC. Risk factors associated with physical restraints in residential aged care facilities: a community based epidemiological survey in Taiwan. Journal of Advanced Nursing 2014; 70(1): 130-143.

7. Registered Nurses' Association of Ontario (RNAO). Promoting Safety: Alternative Approaches to the Use of Restraints. Toronto: Registered Nurses' Association of Ontario, February 2012.

8. National Guideline Clearing House. Guideline Summary, Caregiving strategies for older adults with delirium, dementia and depression supplement. Available from: http://www.guideline.gov/content.aspx?id=32418\&search=restrainton, (2010, accesed, 02 June 2015).

9. Kow JV, Hogan DB. Use of physical and chemical restraints in medical teaching units. Canadian Medical Association or its licensors. CMAJ 2000: 162(3): 339-340.

10. Akansel N. Physical restraint practices among ICU nurses in one university hospital in weastern Turkey. Health Science Journal 2007; 1: 4.

11. Barton-Gooden A, Dawkins P, Bennett J. Physical restraint usage at a teaching hospital: A pilot study. Clinical Nursing Research 2013; June: 1-18.

12. Mohr WK, Theodore AP, Brian DM. Adverse Effects Associated With Physical Restraint. The Canadian Journal of Psychiatry 2003; 48(5): 330-337.

13. Demir A. Nurses' use of physical restraints in four Turkish hospitals. Journal of Nursing Scholarship 2007; 39(1): 38-45.

14. Suen LKP, Lai CKY, Wong TKS, et al. (2006). Use of physical restraints in rehabilitation settings: Staff knowledge, attitudes and prectors. Journal of Advanced Nursing 2006; 55(1): 20-28.

15. Kirsch NR. Ethical Decision Making: Application of a Problem-Solving Model. Topics in Geriatric Rehabilitation 2009; 25(4): 282-291.

16. Lai CKY. Nurses using physical restraints: Are the accused also the victims? - A study using focus group interviews. BMC Nursing 2007; 6: 5 .

17. Springer G. When and how to use restraint. Learn about possible indications for restraint, types of restraints, and how to monitör patients in restraint. American Nurse Today 2015; 10(1), 26-27.

18. Gallagher A. Ethical issues in patient restraint. Nursing Times 2011; 107(9): 18-20.

19. IBM Corp. Released. IBM SPSS Statistics for Windows. Armonk, NY: IBM Corp Version 19.0; 2010.

20. Hemşirelik Yönetmeliğinde Değişiklik Yapılmasına Dair Yönetmelik Resmi Gazete (RG), 08/3/2010, Sayı: 27515. (Regulation on the Amendment of the Nursing Regulation. Offical gazette 08/3/2010, Number: 27515) (in Turkish).

21. Sağlık Hizmetleri Genel Müdürlüğü (SHGM). Sağlıkta Kalite ve Akreditasyon Daire Başkanlığı, 2016, Sağlıkta Kalite Standartları Hastane, Versiyon-5; Revizyon-01. Pozitif Matbaa, ANKARA. (General Directorate of Health Services. Department of Health Quality and Accreditation, 2016, Health Quality Standards Hospital, Version-5; Revision-01. Pozitif Matbaa, ANKARA) (in Turkish).

22. Bradas CM, Sandhu SK, Mion LC. Physical restraints and side rails in acute and critical care settings. In: Boltz M, Capezuti E, Fulmer T, Zwicker D, editor(s). Evidence-based geriatric nursing protocols for best practice. New York (NY): Springer Publishing Company; 2012: 229-245.

23. Joint Commission Standards on Restraint and Seclusion (JCSRS). Nonviolent Crisis Intervention Training Program. Available from: http://www.crisisprevention.com/CPI/media/Media/Resources/alignments/Joint-Commission-Restraint-Seclusion-Alignment-2011.pdf. (2009, accessed, 12 May 2017).

24. Jiang H, Li C, Gu Y, He Y. Nurses' perceptions and practice of physical restraint in China. Nursing Ethics 2015; 22(6): 652-660. 
The Other Side of the Coin: Nurses' Views and Behavior on Physical Restraint - Cemal Huseyin Guvercin et al.

25. Evans D, Wood J, Lambert L. Physical restraint in acute and residential care: a systematic review. Adelaide: The Joanna Briggs Institute; 2002.

26. Fugger G, Gleiss A, Baldinger P, et al. Psychiatric patients' perception of physical restraint. Acta Psychiatrica Scandinavica 2015; 1-11.

27. Raguan B, Wolfovitz E, Gil E. Use of physical restraints in a general hospital: a cross-sectional observational study $I M A J$ 2015; 17(10): 633-638.

28. Allan J. Chief Psychiatrist Policy Physical Restraint Mental Health Act; 2016. Available from https://www.health.qld.gov. au/_data/assets/pdf_file/0027/465174/cpp-physical-restraint.pdf

29. Hofmann H, Schorro E, Haastert B, Meyer G. Use of physical restraints in nursing homes: a multicentre cross-sectional study. BMC Geriatrics 2015; 15: 129.

30. Centers for Medicare \& Medicaid Services (CMMS). State Operations Manual Appendix A - Survey Protocol, Regulations and Interpretive Guidelines for Hospitals; 2014. Revision protocol. Available from http://cms.gov/manuals/Downloads/ som107ap_a_hospitals.pdf.

31. Øye C, Jacobsen FF, Mekki TE. Do organisational constraints explain the use of restraint? A comparative ethnographic study from three nursing homes in Norway. Journal of Clinical Nursing 2016; 26: 1906-1916.

32. Rose C. Choosing the right restraint. Available from https:/www.americannursetoday.com/choosing-restraints/.

33. Heyvaert M, Saenen L, Maes B, Onghena P. (2015). Systematic review of restraint interventions for challenging behaviour among persons with intellectual disabilities: focus on experiences. Journal of Applied Research in Intellectual Disabilities 2015; 28: 61-80.

34. Shalev S. New Zealand human right commission, thinking outside the box? a review of seclusion and restraint practices in New Zealand. 2017: 25-60.

35. Distraction Techniques (DT). Available from https://americannursetoday.com/wp-content/uploads/2015/01/ RoseOnline-sidebars.pdf; (accesed 2015).

36. Potter PA, Perry AG. Fundamentals of nursing concepts, process and practice. 6th edition. St. Louis: The C. V. Mosby Company; 2005: 650-665.

37. Eşer İ, Hakverdioğlu G. Fiziksel tespit uygulamaya karar verme. Cumburiyet Nursing Journal 2006; 10(1): 37-42.

38. Enns E, Rhemtulla R, Ewa VA, Holroyd-Leduc JM. A controlled quality improvement trial to reduce the use of physical restraints in older hospitalized adults. Journal of the American Geriatrics Society 2014; 62(3): 541-545.

39. Evans D, Wood J, Lambert L. Patient injury and physical restraint devices: A systematic review. Journal of Advanced Nursing 2003; 41(3): 274-282.

40. Tullmann DF, Mion LC, Fletcher K, Foreman MD. Delirium. In: Boltz M, Capezuti E, Fulmer T, Zwicker D, editor(s). Evidence-based geriatric nursing protocols for best practice. New York (NY): Springer Publishing Company; 2012: 186199.

41. Fariña-López E, Estévez-Guerra GJ. Physical restraint of patients: historical notes relating to the nineteenth and twentieth century. Revista de Enfermeria (Barcelona, Spain). 2001; 34(3): 22-29.

42. Beauchamp TL, Childress JF. Principles of Biomedical Ethics, 5th edn. NY: Oxford University Press; 2001.

43. Arda B. (2011). Informed consent. 3th edn. Ankara: Ankara University Press.

44. Huizing AR, Hamers JPH, Gulpers MJ, Berger MP. A cluster-randomized trial of an educational intervention to reduce the use of physical restraints with psychogeriatric nursing home residents. Journal of the American Geriatrics Society 2009; 57: 1139-1148.

45. Pérez CAAI, Nicolás OA, Viguria RG, et al. Physical restraint use in critical care units. Perceptions of patients and their families. Enferm Intensiva 2012; 23(2): 77-86.

46. Kandeel NA, Attia AK. Physical restraints practice in adult intensive care units in Egypt. Nursing and Health Sciences 2013; 15: 79-85.

47. Cheung PPY, Yam BMC. Patient autonomy in physical restraint. Journal of Clinical Nursing 2004; 14(3a): 34-40.

Received: April 24, 2018

Accepted: May 17, 2018 